Article

\title{
Biomimetic Oxidation of Benzofurans with Hydrogen Peroxide Catalyzed by Mn(III) Porphyrins
}

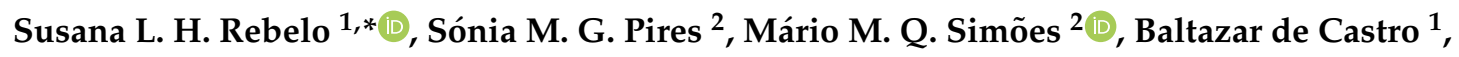

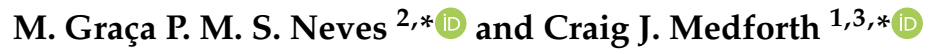 \\ 1 LAQV-REQUIMTE, Department of Chemistry and Biochemistry, Faculty of Sciences, University of Porto, \\ Rua do Campo Alegre, 4169-007 Porto, Portugal; bcastro@fc.up.pt \\ 2 QOPNA \& LAQV-REQUIMTE and Department of Chemistry, University of Aveiro, \\ 3810-193 Aveiro, Portugal; sonia.pires@ua.pt (S.M.G.P.); msimoes@ua.pt (M.M.Q.S.) \\ 3 Department of Chemistry, University of California, One Shields Avenue, Davis, CA 95616, USA \\ * Correspondence: susana.rebelo@fc.up.pt (S.L.H.R.); gneves@ua.pt (M.G.P.M.S.N.); \\ cjmedforth@ucdavis.edu (C.J.M.)
}

Received: 28 September 2019; Accepted: 18 December 2019; Published: 1 January 2020

check for updates

\begin{abstract}
The modelling of metabolic activation of the benzofuran nucleus is important to obtain eco-sustainable degradation methods and to understand the related mechanisms. The present work reports the catalytic oxidation of benzofuran, 2-methylbenzofuran, and 3-methylbenzofuran by hydrogen peroxide, at room temperature, in the presence of different $\mathrm{Mn}$ (III) porphyrins as models of cytochrome P450 enzymes. Conversions above 95\% were attained for all the substrates. The key step is the formation of epoxides, which undergo different reaction pathways depending on factors, such as the position of the methyl group and the reaction and work-up conditions used.
\end{abstract}

Keywords: benzofurans; biomimetic oxidation; catalysis; manganese porphyrins; hydrogen peroxide

\section{Introduction}

The enzymes of the cytochrome P450 (CYP) group play a central role in the metabolism of xenobiotics [1,2]. These enzymes have been identified in all forms of living organisms, from mammals to bacteria, and mainly define the biological action of drugs and pollutants, as well as their environmental fate [3]. CYPs act during phase I of metabolism, performing oxygenation of the substrate [1], and have a significant part in the overall metabolism, and were found to be responsible for about $75 \%$ of the known enzymatic reactions on drugs [4].

The possibility of modulating the metabolic activation of these enzymes using synthetic metalloporphyrins has been studied extensively in the last decades [5-9]. In this context, metalloporphyrins carrying electron-withdrawing moieties have succeeded in modelling CYPs active center that includes the iron complex of protoporphyrin IX (heme group) [10,11]. Efficient biomimetic approaches have advantages, as synthetic porphyrins are readily available and much easier to handle than the purified enzymes [7].

Biomimetic processes are also a convenient alternative for eco-sustainable oxidation processes, since they allow the use of green oxidants, such as $\mathrm{H}_{2} \mathrm{O}_{2}$ or $\mathrm{O}_{2}$ (that afford water as the only by-product), and mild conditions [12-17]. This leads to a significant reduction of environmental impact relative to stoichiometric oxidants, such as $\mathrm{Cr}_{2} \mathrm{O}_{7}{ }^{2-}, \mathrm{MnO}_{4}{ }^{-}$, and dimethyldioxirane (DMD), or milder but expensive oxidants that also generate sub-products, such as $m$-chloroperoxybenzoic acid ( $m$-CPBA), $\mathrm{PhIO}, \mathrm{ClO}^{-}, \mathrm{HSO}_{5}{ }^{-}$, and $\mathrm{IO}_{4}{ }^{-}$.

Benzofurans are among the pollutants found in the environment as a result of waste incineration and as exhaust gases of gasoline and diesel engines [18]. The 2,3-benzofuran is known to be toxic and 
is associated with mutagenesis and carcinogenesis. As for other polycyclic aromatic compounds, its toxicity is attributed to the formation of the reactive arene oxide in vivo during its metabolism [19], which then readily reacts with biomolecules, including DNA. On the other hand, a broad spectrum of clinically approved pharmaceuticals contain the benzofuran nucleus decorated with different functionalities [20,21]. Compounds containing the benzofuran core structure show antimicrobial [22], anti-inflammatory [23], antitumor [24], or antioxidant activity [25]. Moreover, a series of benzofuran derivatives is already being used to treat Alzheimer's disease [26]. Thus, the study of biomimetic oxidations of benzofurans is important for a further understanding of their metabolic pathways and toxicity mechanisms.

The oxidation of substituted 2,3-benzofurans has already been studied with $m$-CPBA or DMD as oxidants, leading to reactive epoxides that can be further oxidized, affording ring-opening products, such as keto esters, spiroepoxides, and benzodioxole (Figure 1; right side) [27]. The profile of these reactions depends on the substituents, amount of oxidant, and temperature. Additionally, the epoxides can be rearranged at room temperature, affording benzofuranones resulting from 1,2-alkyl migration and allylic alcohols from hydrogen transposition (Figure 1; left side) [27].
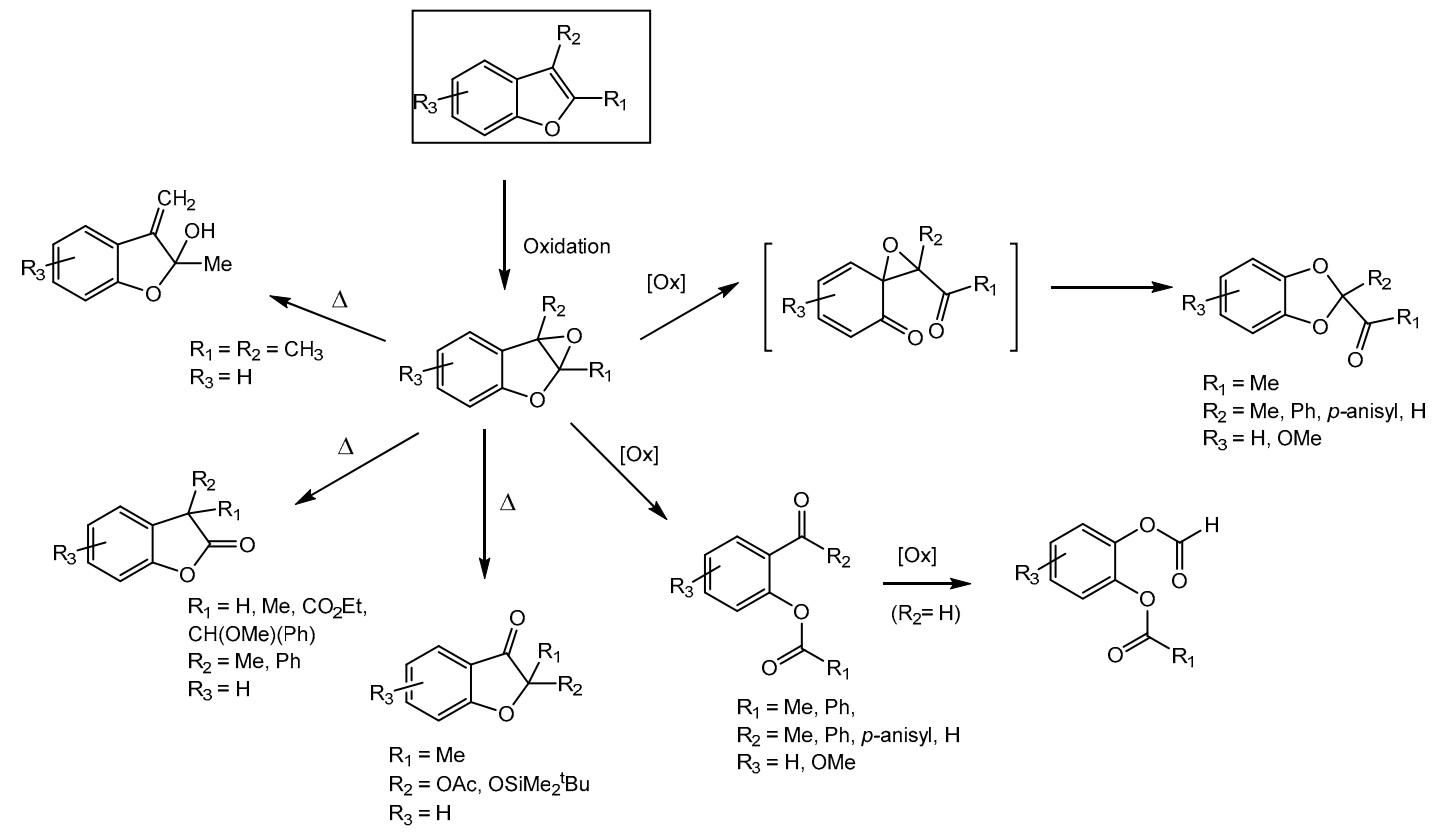

Figure 1. Most common isolated products from the oxidation of substituted benzofurans with $m$-CPBA or dimethyldioxirane (adapted from [27]).

The oxidation of benzofuran (BF), 2-methylbenzofuran (2MBF), and 3-methylbenzofuran (3MBF) in the presence of an $\mathrm{Fe}(\mathrm{III})$ porphyrin and hydrogen peroxide was recently reported by us, and afforded a one-pot, green, and versatile method for the synthesis of novel and biologically active compounds [28]. The significantly different reactivity observed for iron and manganese porphyrins has been ascribed to the formation of different catalytic intermediates [10,29]. Some Mn(III) porphyrins have been used with success as models of CYPs in the oxidation of aromatic compounds, leading mainly to arene oxide products $[19,30]$. These systems required the presence of a co-catalyst for the activation of $\mathrm{H}_{2} \mathrm{O}_{2}$ [31] and their action has been ascribed to the typical reactivity of a metalloporphyrin oxo-species $[\mathrm{Mn}(\mathrm{V})=\mathrm{O}]$ intermediate [29].

The present study describes the oxidation of $\mathbf{B F}, 2 \mathrm{MBF}$, and $3 \mathrm{MBF}$ by hydrogen peroxide in the presence of the three manganese(III) porphyrin complexes depicted in Figure 2. The product mixtures are analyzed and mechanisms proposed for the transformations of the benzofurans using these biomimetic conditions. 
a)

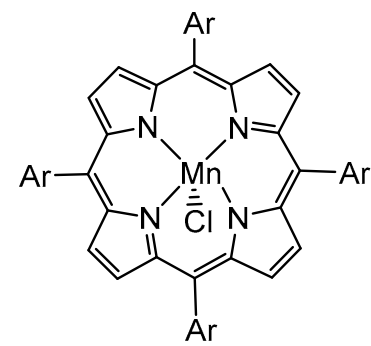

b)

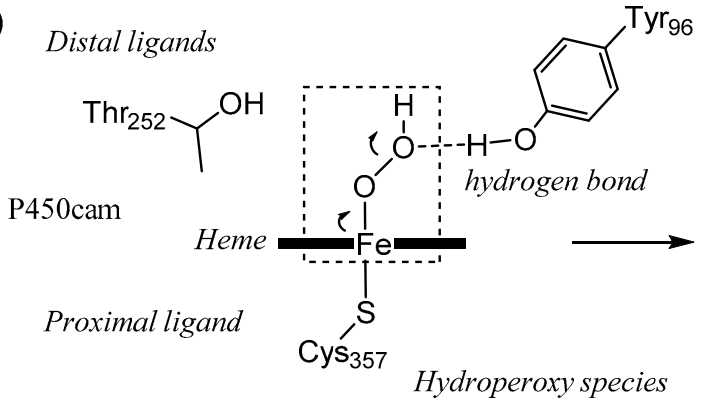

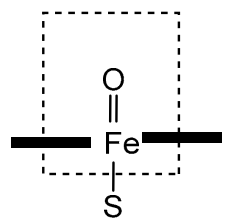

Oxo species<smiles></smiles>

II)<smiles>Fc1c(F)c(F)c([131I])c(F)c1F</smiles>

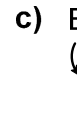

c) $\mathrm{B}$ $\stackrel{+}{\mathrm{BH}}$<smiles></smiles>

Figure 2. Biomimetic systems: (a) structures of the $\mathrm{Mn}(\mathrm{III})$ porphyrins used as catalysts; (b) adapted representation of $\mathrm{P} 450$ cam active site [10]; (c) mechanism proposed for the biomimetic generation of oxo-species, where the co-catalysts mimic the action of proton-donating amino acids from the P450 active site.

\section{Results and Discussion}

\subsection{Comparisons of Metalloporphyrin Catalyst Performance}

The oxidation of benzofurans by hydrogen peroxide was evaluated in the presence of the second generation manganese(III) catalysts presented in Figure 2a and referred to from now on as CAT I, II, and III. Neutral Mn(III) porphyrins I and II were prepared by a microwave procedure in eco-sustainable conditions using nonhazardous solvents [32,33]. The catalytic reactions were carried out at room temperature with acetonitrile as the reaction solvent and in the presence of a co-catalyst that mimics the proton-donating amino acids in the active site of CYPs (Figure 2b) [10]. The co-catalysts provide the appropriate proton concentration for generation of the active oxidant, which is considered to be the high-valent oxo-species. This is proposed to occur by successive deprotonation/protonation steps (Figure 2c). Ammonium acetate (buffer $\mathrm{pH} 7$ ) was shown to be an efficient co-catalyst for CAT I and CAT II [31,34], whereas for CAT III the best co-catalyst was acetic acid [35]. This difference can be explained by the presence of positive groups in CAT III, which induce greater acidity at the Mn center and lead to the need for a more acidic medium in the protonation and dehydration steps (Figure 2c). When using $\mathrm{H}_{2} \mathrm{O}_{2}$ as the oxidant, the absence of a co-catalyst leads to inactivation of the biomimetic systems [31].

The hydrogen peroxide was progressively added to the reaction mixture at a constant rate of $0.6 \mathrm{mmol} / \mathrm{h}$ (two equivalents of oxidant per hour for each equivalent of substrate) and the reactions were monitored by GC-FID until no additional conversion of substrate was observed. Figure 3 shows the results obtained with a catalyst loading of $0.3 \mathrm{~mol} \%$. The systems based on CATs I and III show a substrate conversion always higher than $95 \%$, while systems based on CAT II are slightly less efficient and show substrate conversions in the range $80 \%-94 \%$. The reaction times depend on the substrate and catalyst, but the reactions were typically complete after 2 to $4 \mathrm{~h}$. The slightly lower activity of CAT II compared to CAT I might be explained by a higher oxidation potential (due to the electron-withdrawing fluorine groups) hampering formation of the oxo-species (Figure 2c) [29]. A higher catalyst loading of $0.7 \mathrm{~mol} \%$ was also tested (see the Supplementary Material, Section S1, Figure S1). Reaction completion times were the same as or shorter than those shown in Figure 3. Higher conversions were also observed, especially for CAT II. 


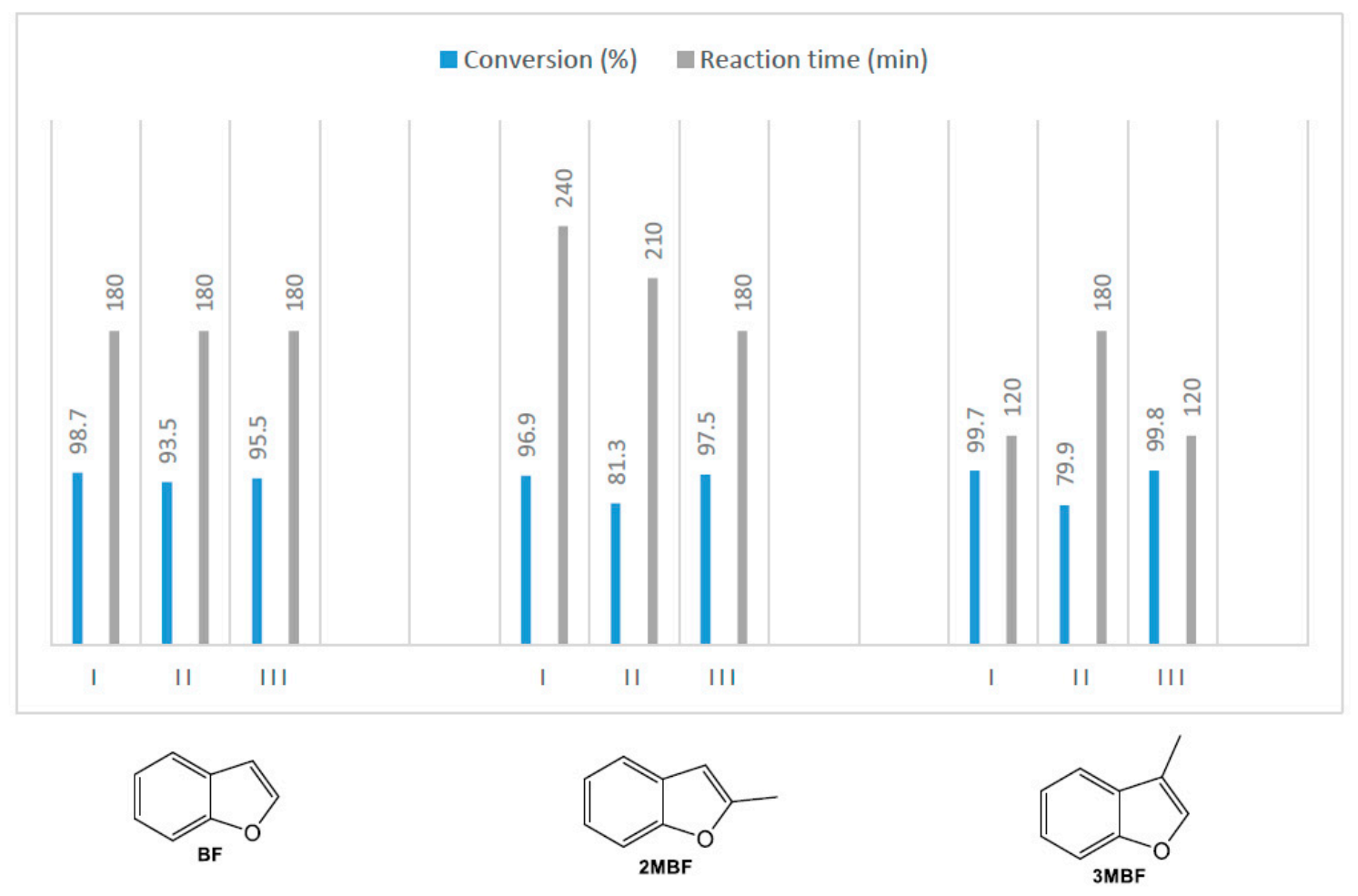

Figure 3. Results of catalytic oxidation of benzofuran (BF), 2-methylbenzofuran (2MBF), and 3-methylbenzofuran (3MBF) in the presence of metalloporphyrins (I-III) in acetonitrile and using a catalyst loading of $0.3 \mathrm{~mol} \%$.

Control experiments were performed for the three substrates. No substrate conversion was observed during a period of $3 \mathrm{~h}$ before $\mathrm{H}_{2} \mathrm{O}_{2}$ addition, indicating that molecular oxygen is not being used as an oxidant by the catalysts. For reactions in the absence of catalyst, no significant conversion of the substrate was detected $(<10 \%)$.

\subsection{Benzofuran (BF) Oxidation Reactions}

Analysis by GC-FID of the $\mathbf{B F}$ oxidation reactions using the CAT $\mathbf{I} / \mathrm{NH}_{4} \mathrm{AcO}$ catalytic system showed high substrate conversion even though only a single small product peak was detected (Figure 4). The product was identified by GC-MS as salicylaldehyde [1 (SA), Scheme 1] $\left(\mathrm{M}^{+\bullet}\right.$ at $m / z$ 122.1). After 3 $\mathrm{h}$ corresponding to a ratio oxidant/substrate (Ox/S) of 6, SA was obtained in a $15 \%$ yield (based on the SA concentration in the mixture measured by the GC internal standard method).

The formation of $\mathbf{S A}$ can be explained as proposed in Scheme 1 for $\mathbf{B F}\left(\mathrm{R}_{1}=\mathrm{R}_{2}=\mathrm{H}\right)$, leading to SA and formaldehyde.

The low yield of SA shows that other compounds are being formed which are not detected by GC. In order to identify other possible reaction products, the $\mathbf{B F}$ reaction mixtures formed in the presence of CAT I and $\mathrm{NH}_{4} \mathrm{AcO}$ were analyzed by high resolution mass spectrometry with electrospray ionization in the positive mode (HRMS-ESI ${ }^{+}$) and tandem $\mathrm{MS}^{\mathrm{n}}$ studies.

Previous work on the biomimetic oxidation of $\mathrm{BF}$ using iron porphyrins has shown that the products formed depend on the solvent evaporation temperature and on the Ox/S ratio [28]. Lower $\mathrm{Ox} / \mathrm{S}$ ratios resulted in less degradation of the BF ring system. For reactions investigated with an $\mathrm{Ox} / \mathrm{S}$ ratio of 4, the compositions of the final reaction mixtures were analyzed by MS studies before solvent evaporation, after solvent evaporation at RT, and after solvent evaporation at $30^{\circ} \mathrm{C}$ (Figure $5 \mathrm{a}-\mathrm{c}$ ). Then, the mass spectra of reactions with Ox/S ratios of 4 and 6 were compared for solvent evaporation at RT (Figure 5b,d). 


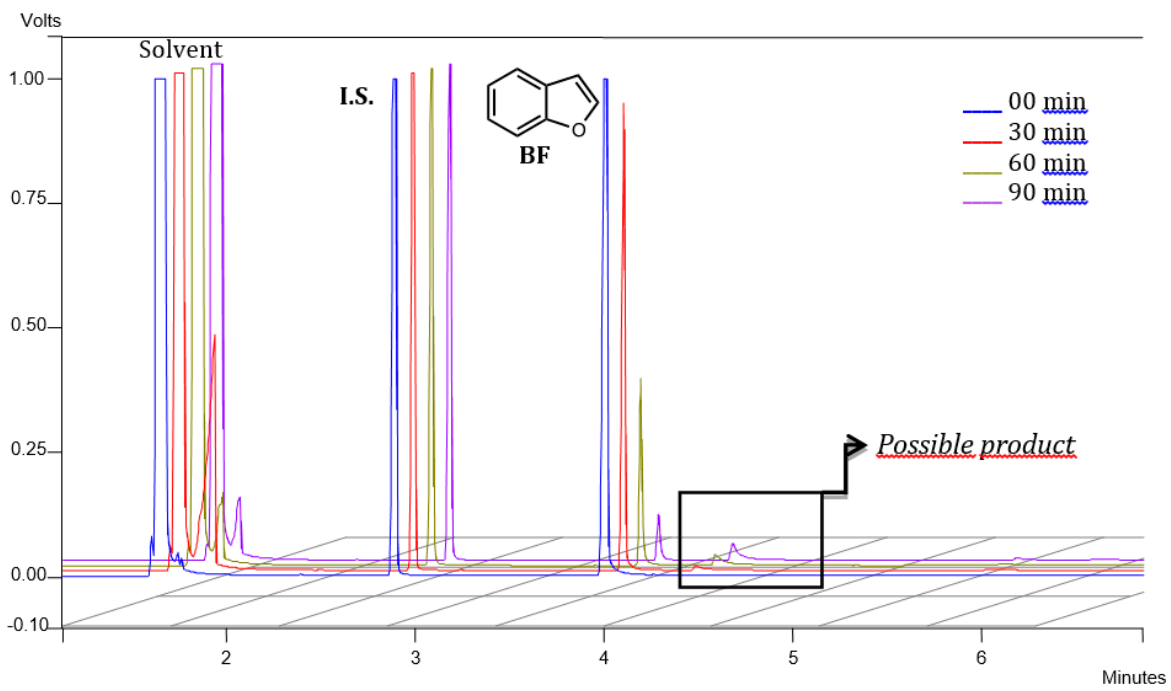

Figure 4. GC-FID chromatograms (between 0-90 min) for BF oxidation by $\mathrm{H}_{2} \mathrm{O}_{2}$ using CAT I and ammonium acetate as co-catalyst.

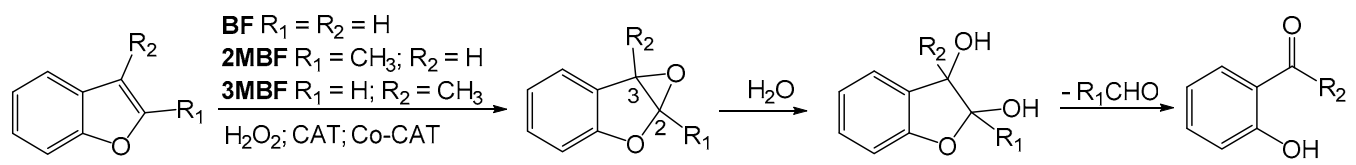

Scheme 1. Decomposition of epoxide derivatives of BF, 2MBF, and 3MBF.

The ions detected (Figure 5e) were analyzed by detailed HRMS ${ }^{\mathrm{n}}$ studies. The MS ${ }^{\mathrm{n}}$ spectra of the 15 products $(\mathbf{1 a}, \mathbf{2}-\mathbf{4}, \mathbf{5 a}, \mathbf{6}-\mathbf{1 5})$ and the observed fragments are given in Figures S2-S16 of the Supplementary Materials. A detailed reaction scheme with suggested mechanisms for the formation of these products is shown in Scheme 2.

All the ions detected contained nitrogen, indicating reactions with ammonia from the $\mathrm{NH}_{4} \mathrm{AcO}$ co-catalyst. Protonation in the MS source is much easier for the nitrogen versus oxygen groups, probably contributing to the predominance of signals observed for the protonated nitrogen species. Most of the products were only identified by mass spectrometry, but compounds $1 \mathbf{a}$ and $5 \mathbf{a}$ were isolated as the carbonyl derivatives $\mathbf{1}$ and $\mathbf{5}$ (see below).

The observed products can be justified by considering the initial reaction of $\mathbf{B F}$ oxide (BF-O) to afford SA (1) and BF-NH $\mathbf{N H}_{2}$ as primary products (Scheme 2a). Nucleophilic attack of $\mathbf{B F - O}$ by $\mathrm{NH}_{3}$ present in the reaction media (from the $\mathrm{NH}_{4}{ }^{+} / \mathrm{NH}_{3}$ equilibrium of the $\mathrm{NH}_{4} \mathrm{AcO}$ co-catalyst) might afford $\mathbf{B F}-\mathrm{NH}_{2}$, and $\mathrm{NH}_{3}$ might also react with the carbonyl group SA to form the corresponding imine (1a, Scheme 2a).

Oxirane ring opening by SA affords compound 5 (Scheme 2b), which may undergo further reactions, such as imine formation to $5 \mathbf{a}$, oxidation to the oxo derivative (5-ox), and elimination of water, which are key steps in the formation of the other derivatives $(\mathbf{2}, 4,8,9, \mathbf{1 0}, \mathbf{1 1})$ presented in Scheme $2 b$.

The products presented in Scheme $2 c$ can be explained as a result of dimerization reactions between two salicylic units, followed by transformations such as oxidation (3 and $\mathbf{6})$, reaction with BF-O, and elimination of water (12).

Another set of products results from the reaction between $\mathbf{B F}-\mathbf{N H}_{\mathbf{2}}$ and $\mathbf{B F - O}$ (Scheme 2d) to afford intermediate BF-2 through successive epoxide ring opening, oxidation of hydroxyl group to an oxo derivative, and dehydration. BF-2 is the key intermediate in the intramolecular cyclisation reaction (through imine-double bond reactions) to afford compound 7 [36] and in the reaction with SA (imine form, 1a) to afford 13. Further reaction of $\mathbf{7}$ with SA affords 14. Derivative $\mathbf{1 5}$ results from the condensation reaction of $\mathbf{B F - N _ { 2 }}$ with the imine form of 5-ox. 

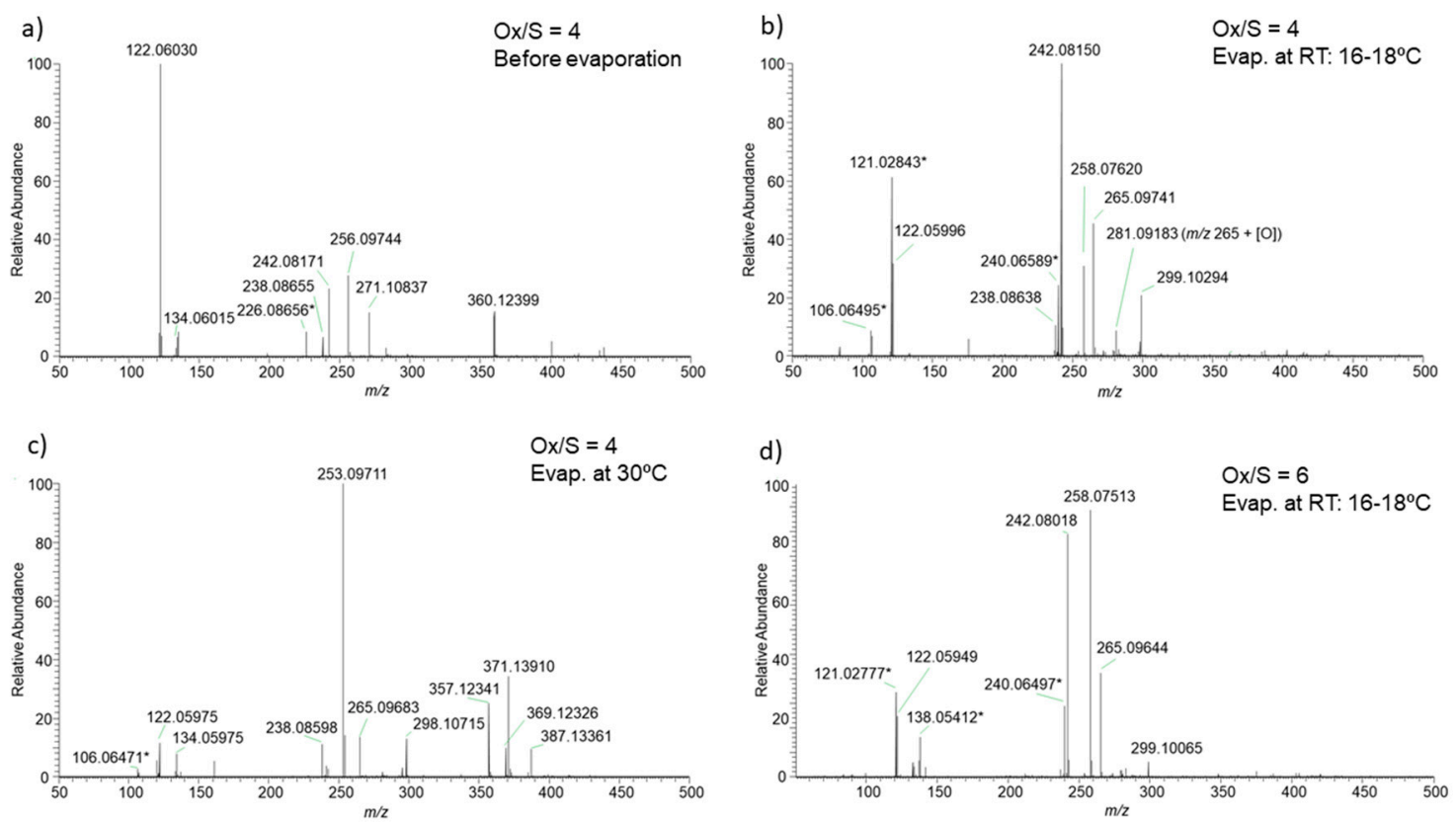

e)
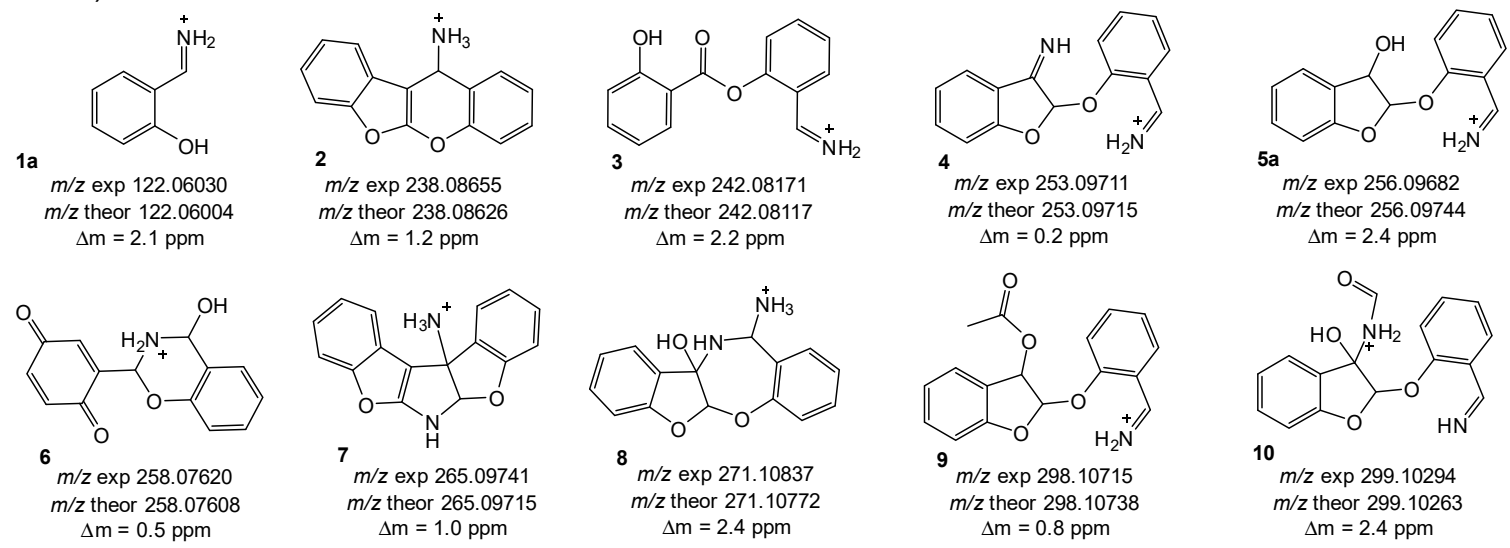

10

$m / z$ exp 299.10294 $\mathrm{m} / \mathrm{z}$ theor 299.10263
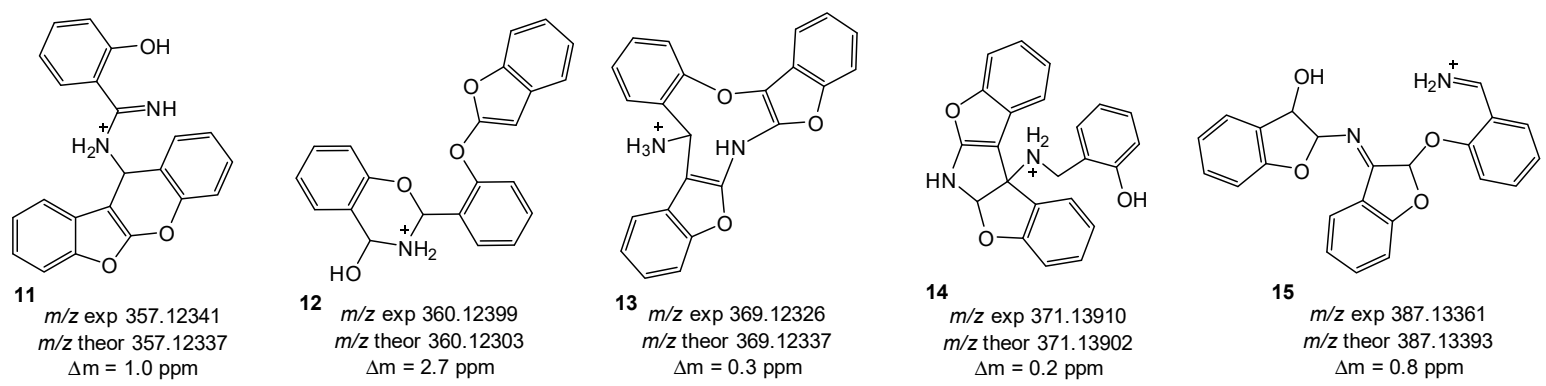

15 $m / z \exp 387.13361$ $\Delta \mathrm{m}=0.8 \mathrm{ppm}$

Figure 5. (a-d) Mass spectra of $\mathbf{B F}$ oxidation reaction mixtures in the presence of CAT I and $\mathrm{NH}_{4} \mathrm{AcO}$, using Ox/S ratios of 4 or 6 and obtained before and after evaporation; (e) structure of mass ions identified during HRMS ${ }^{n}$ analyses, in ascending order of $\mathrm{m} / \mathrm{z}$. The oxo forms of $\mathbf{1} \mathbf{a}$ and $\mathbf{5 a}$ were also characterized by NMR spectroscopy.

It is noteworthy that the mass spectrum pattern is different before and after solvent evaporation (Figure $5 \mathrm{a}-\mathrm{c}$ ). This can be explained by reactions between the primary products being formed (Scheme 2a), which increases during the concentration of the reaction mixture. After evaporation, the reaction mixtures show major ions corresponding to products with $\mathrm{m} / \mathrm{z}>200$. The products formed also depend on the evaporation temperature. Finally, when the work-up consists of solvent evaporation at 
RT and an Ox/S ratio of 4 vs. 6 (Figure $5 \mathrm{~b}, \mathrm{~d}$ ), similar molecular ions are observed. However, for Ox/S 6 the most intense signal is seen for the more oxygenated species $6(\mathrm{~m} / \mathrm{z} 258)$ instead of $3(\mathrm{~m} / \mathrm{z} 242)$.

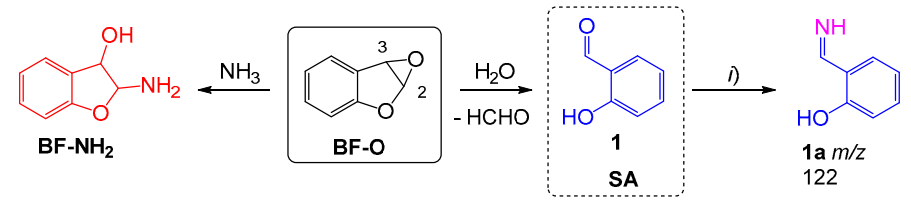

b)

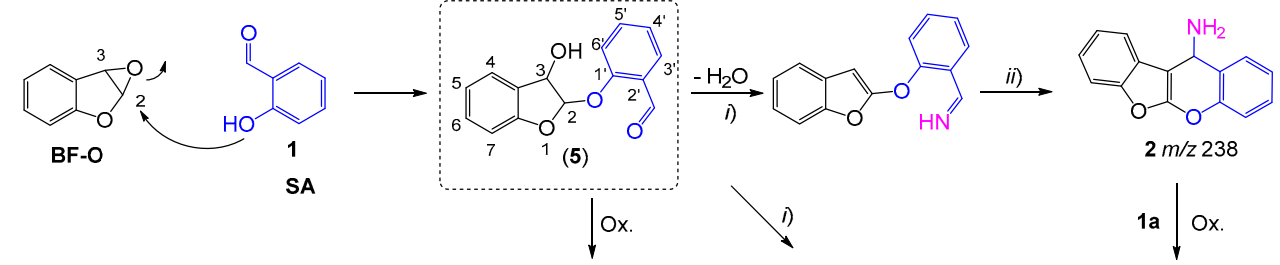

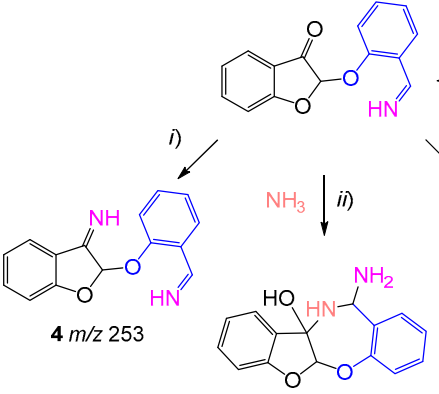

$8 \mathrm{~m} / \mathrm{z} 271$
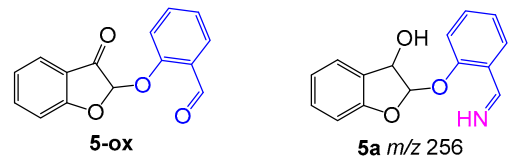
$\mathrm{CH}_{3} \mathrm{COOH} \downarrow-\mathrm{H}_{2} \mathrm{O}$
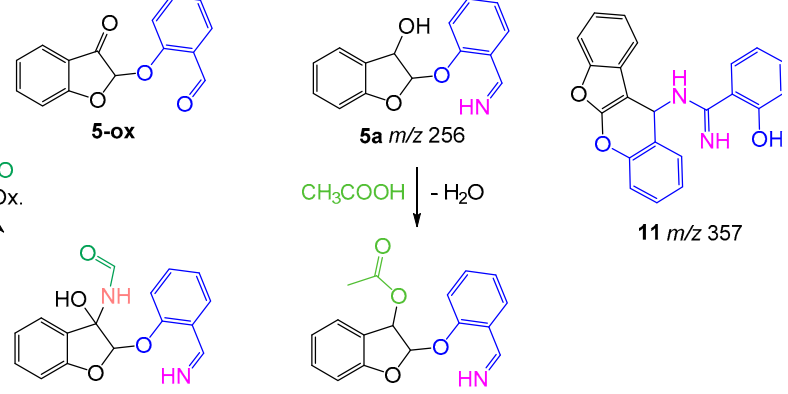

c)

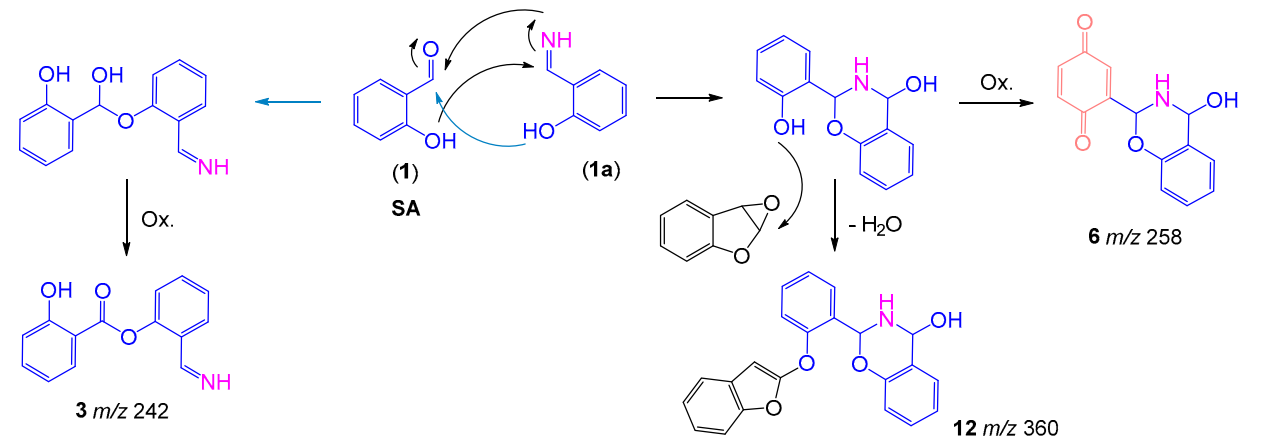

d)

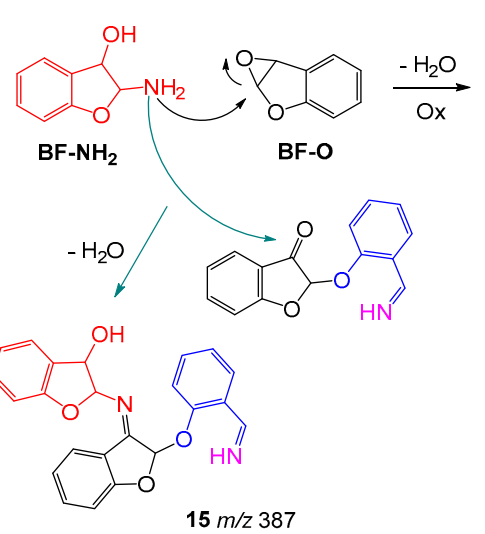

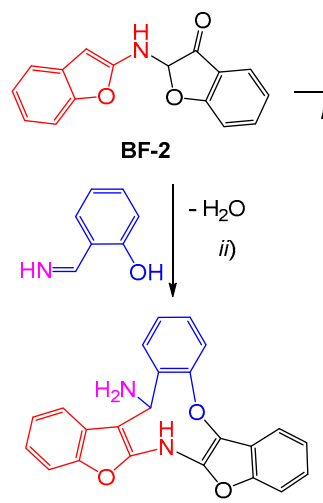

$13 \mathrm{~m} / \mathrm{z} 369$
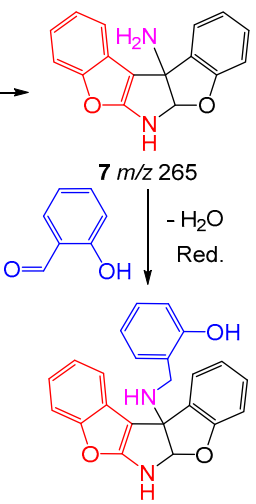

$14 \mathrm{~m} / \mathrm{z} 371$

Scheme 2. Reaction schemes proposed for the formation of BF products occurring by: (a) reaction of BF oxide (BF-O) with $\mathrm{H}_{2} \mathrm{O}$ or $\mathrm{NH}_{3}$; (b) reaction of BF-O with salicylaldehyde (SA); (c) reaction between two salicyl units; (d) reaction of $\mathbf{B F - O}$ with an amino derivative $\left(\mathbf{B F}-\mathbf{N H}_{2}\right)$. (i) imine formation $\left(\mathrm{NH}_{3} ;-\mathrm{H}_{2} \mathrm{O}\right)$; (ii) intramolecular cyclization. The $m / z$ values correspond to $[\mathrm{M}+\mathrm{H}]^{+}$ions identified by HRMS $^{n}$. Compounds $\mathbf{1}$ and $\mathbf{5}$ were also characterized by NMR spectroscopy. 
With the objective of isolating some of the compounds detected by mass spectrometry, the reaction mixture resulting from BF oxidation using an Ox/S ratio of 4 was fractionated by preparative TLC before solvent evaporation (conditions of Figure 5a). The position of the compounds in the TLC plates was revealed with concentrated $\mathrm{H}_{2} \mathrm{SO}_{4}$ (see Experimental Section). TLC fractionation afforded compounds 1 ( $30 \%$ yield) and $\mathbf{5}$ ( $25 \%$ yield) (Scheme $2 \mathrm{~b}$, inside a dashed frame) which were analyzed by NMR spectroscopy (see Experimental Section and Figures S19 and S20). The higher yield obtained for 1 (SA) in the present conditions (30\%) relative to that obtained by GC-FID analysis (15\%) can be justified by the lower Ox/S ratio (4 vs. 6) and by the high temperature of the FID injector $\left(200{ }^{\circ} \mathrm{C}\right)$ which can promote coupling reactions involving SA leading to non-volatile products.

The fractionation by TLC of a similar reaction after solvent evaporation in the hood at 16 to $18^{\circ} \mathrm{C}$ (conditions of Figure $5 \mathrm{~b}$ ) afforded a fraction containing the ion $\mathrm{m} / \mathrm{z} 265.10$ that was assigned to compound 7 (Scheme $2 \mathrm{~d}$ and Figure S8). The compound corresponding to the intense peak at $\mathrm{m} / \mathrm{z}$ 242 (3, Scheme 2c) was not isolated by preparative TLC, probably because it results from hemiacetal formation between two SA units (Scheme 2c), which is a reversible reaction, and oxidation to the ester occurs in the MS source.

Notably, when the oxidation reaction of BF in the presence of CAT III with acetic acid as co-catalyst and an Ox/S ratio of 6 was analyzed by GC-MS (EI), only a single product is observed with a molecular ion at $m / z 140$ corresponding to SA plus a water molecule.

According to a SciFinder ${ }^{\mathrm{TM}}$ search, compound 5 has not previously been reported.

\subsection{Oxidation Products of 2-Methylbenzofuran (2MBF)}

The oxidation reactions of $2 \mathrm{MBF}$ were also investigated in the presence of CAT I and $\mathrm{NH}_{4} \mathrm{AcO}$, using an $\mathrm{Ox} / \mathrm{S}$ ratio of 4 , and the solvent evaporated in the hood at $20^{\circ} \mathrm{C}$. These conditions are similar to those used for BF in Figure $5 \mathrm{~b}$. The products were identified by high resolution ESI-MS ${ }^{\mathrm{n}}$ (Supplementary Materials, Figure S17). The reaction mixture was then fractionated by preparative TLC with the three fractions isolated showing mass spectra corresponding to compounds 16-18 (Scheme 3a). $\mathrm{MS}^{\mathrm{n}}$ spectra and mass fragment analyses are collected in Figures S17 and S18 of the Supplementary Material. Compound $\mathbf{1 6}$ was also analyzed by NMR in $\mathrm{CDCl}_{3}$ (see Experimental and Supplementary Material, Figure S21) as the oxo form (ring-opened). In DMSO- $\mathrm{d}_{6}$, a hydrogen-bond acceptor solvent, the hemiacetal form (ring-closed) of $\mathbf{1 6}$ was detected [28].

A rationalization for the formation of compounds 16-18 is shown in Scheme $3 \mathrm{~b}$. Initial formation of $2 \mathrm{MBF}$ oxide (2MBF-O) is followed by a sequence of reactions after the epoxide ring-opening in the presence of nucleophiles (Scheme $3 b$ ). The $\mathrm{AcOH}$ required for the formation of compound 16 results from the use of $\mathrm{NH}_{4} \mathrm{AcO}$ as the co-catalyst. Moreover, in accordance with Scheme 1 for $2 \mathrm{MBF}$ $\left(\mathrm{R}_{1}=\mathrm{CH}_{3} ; \mathrm{R}_{2}=\mathrm{H}\right)$, the cleavage of the 2MBF-diol intermediate and decarboxylation leads to SA (1) and acetaldehyde which are involved in the formation of compounds $\mathbf{1 7}$ and $\mathbf{1 8 .}$

The nucleophilic attack on 2MBF-O at the less electron-deficient carbon (position-3) might be justified by the steric hindrance of the methyl group at position-2. Reaction of $2 \mathrm{MBF}-\mathrm{O}$ with acetic acid produces compound 16. On the other hand, the attack of salicylaldehyde (SA) at position-3 of 2MBF oxide affords intermediate I and its open form (oxo) in a keto-enol equilibrium. The enol can undergo intramolecular cyclisation reaction between the double bond and the imine group (similar to that described for formation of compound 7) and evolve to six-side (I-s6) or five-side (I-s5) intermediates. Evolution of I-s6 through oxidation and reaction with $\mathrm{NH}_{3}$ and acetaldehyde justifies the formation of compound 17. The I-s5 is proposed to evolve to $\mathbf{1 8}$ through the loss of a phenol moiety concomitant to aromatization followed by an imine-imine coupling reaction.

According to a SciFinder ${ }^{\mathrm{TM}}$ search, compound $\mathbf{1 6}$ (in closed or open forms) has not previously been reported. 
a)

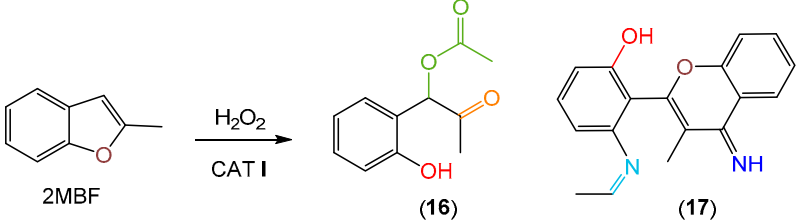

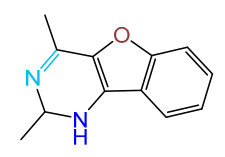

(18)

b)
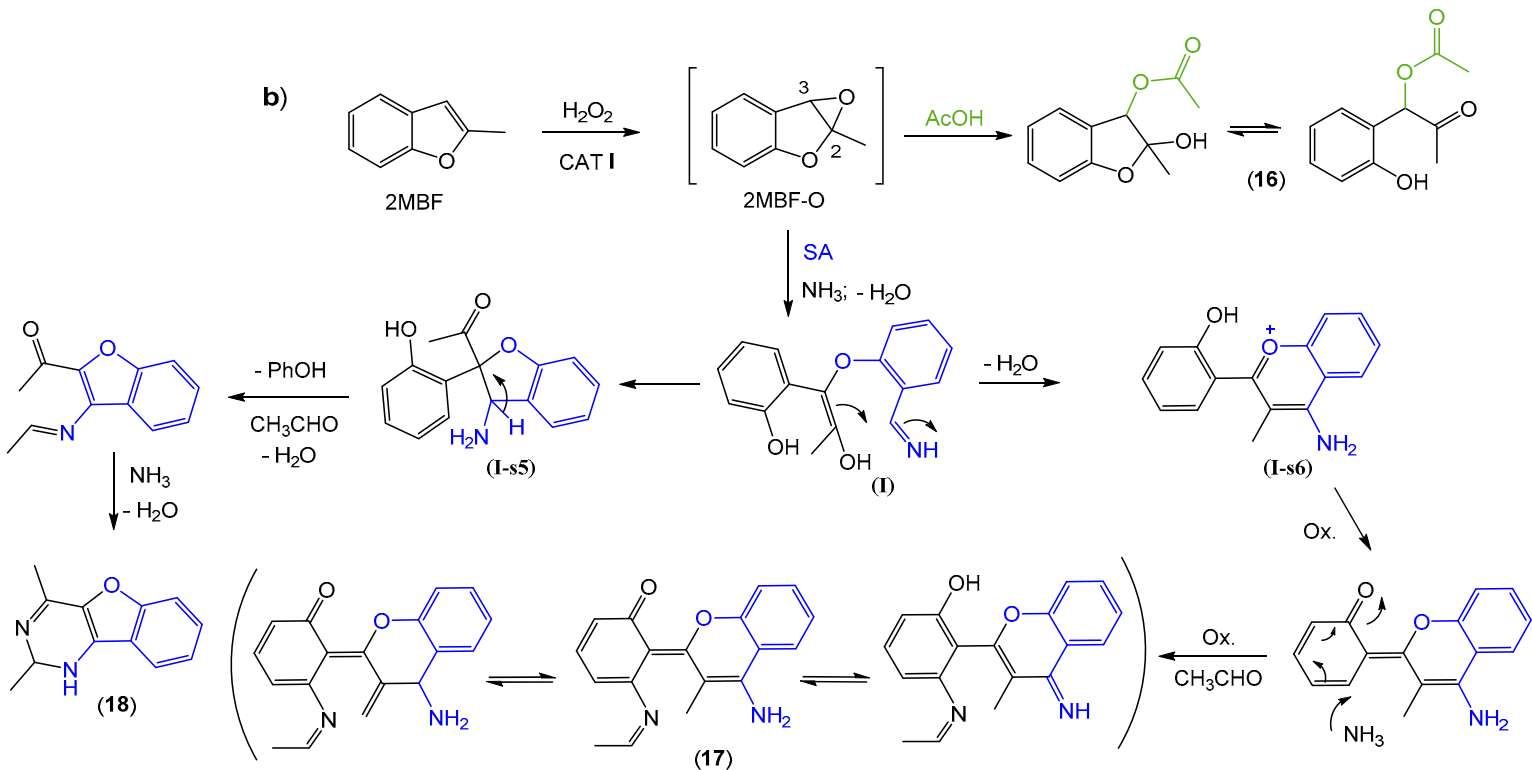

Scheme 3. (a) Major products identified by HRMS ${ }^{\mathrm{n}}$ studies in the $2 \mathrm{MBF}$ oxidation reactions and (b) a mechanistic proposal for their formation. Compound 16 was also identified by ${ }^{1} \mathrm{H}$ and ${ }^{13} \mathrm{C}$ NMR spectroscopy.

\subsection{Oxidation of 3-Methylbenzofuran (3MBF)}

Finally, the catalytic oxidation reactions of 3MBF were investigated. The final reaction mixture obtained in the presence of CAT I and $\mathrm{NH}_{4} \mathrm{AcO}$ with $\mathrm{Ox} / \mathrm{S}=4$ was analyzed by GC-MS; the major product was identified as the lactone 19 (3-methylbenzofuran-2(3H)-one), and the minor one as 2'-hydroxyacetophenone 20 (Scheme 4). ${ }^{1} \mathrm{H}$ NMR analysis of the total reaction mixture confirmed the identification of the compounds (see Experimental Section and the Supplementary Material, Figures S22 to S25) and also that no other products were present in the reaction mixture except for traces of the substrate $3 \mathrm{MBF}$.

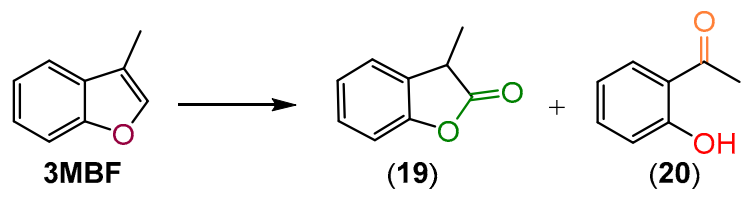

Scheme 4. Products from $3 \mathrm{MBF}$ oxidation reactions identified by GC-MS and ${ }^{1} \mathrm{H}$ NMR of the total reaction mixtures. Compounds 19 and 20 were also identified by ${ }^{1} \mathrm{H}$ NMR spectroscopy.

The formation of compound $\mathbf{1 9}$ can be explained as depicted in Scheme 5. After the epoxidation at the 2,3-positions of $\mathbf{3 M B F}$, there is an internal rearrangement of the oxirane ring in $3 \mathrm{MBF}-\mathrm{O}$ to the enol derivative (3-methylbenzofuran-2-ol). Once formed, the enol moiety can be in equilibrium with the corresponding keto form, which is a particularly stable structure due to the lactone group. An alternative pathway is the epoxide ring opening to the diol followed by water elimination. Compound $\mathbf{2 0}$ may form in accordance with the mechanism described in Scheme 1 for $3 \mathrm{MBF}\left(\mathrm{R}_{1}=\mathrm{H} ; \mathrm{R}_{2}=\mathrm{CH}_{3}\right)$. 


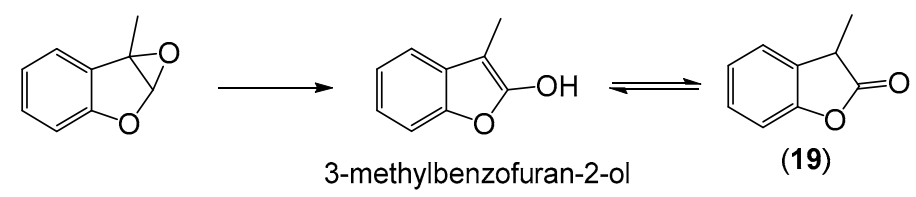

Scheme 5. Conversion of 3MBF oxide into the lactone derivative.

The number of products obtained when $3 \mathrm{MBF}$ is oxidized is strikingly small compared to the large number of compounds seen for the oxidation of BF. Moreover, a similar product profile was noted when GC-FID was used to quantify the products and to obtain the conversions and selectivities for the different catalysts I, II, and III (Table 1). Only minor differences in conversions and selectivity are observed (Table 1). CATs I and III led to near full conversion after $2 \mathrm{~h}$ using a catalyst loading of $0.3 \mathrm{~mol} \%$ and after $1.5 \mathrm{~h}$ using $0.7 \mathrm{~mol} \%$. In contrast, in the presence of CAT II, $80 \%$ conversion is obtained after $4 \mathrm{~h}$ for $0.3 \mathrm{~mol} \%$ of catalyst.

Table 1. Selectivity observed with Mn(III) catalysts I-III in the oxidation of $3 \mathbf{M B F}$ by $\mathrm{H}_{2} \mathrm{O}_{2}$.

\begin{tabular}{cccccc}
\hline \multirow{2}{*}{ Catalyst } & \multirow{2}{*}{ Loading (mol\%) } & \multirow{2}{*}{ Conversion (\%) } & \multirow{2}{*}{ Time (min) } & \multicolumn{2}{c}{${\text { Selectivity }(\eta)^{\mathbf{a}}}^{\mathbf{a}}$} \\
\cline { 5 - 6 } & & & & $\mathbf{1 9}$ & $\mathbf{2 0}$ \\
\hline I & 0.3 & 99.7 & 120 & $91.9(91.6)$ & $8.1(8.1)$ \\
I & 0.7 & 99.9 & 90 & $88.3(88.2)$ & $11.7(11.7)$ \\
II & 0.3 & 79.9 & 240 & $86.8(69.4)$ & $13.2(10.5)$ \\
II & 0.7 & 84.3 & 180 & $87.0(73.3)$ & $13.0(11.0)$ \\
III & 0.3 & 99.8 & 120 & $98.8(98.6)$ & $1.1(1.1)$ \\
III & 0.7 & 99.9 & 90 & $98.4(98.3)$ & $1.6(1.6)$ \\
\hline
\end{tabular}

${ }^{\text {a }}$ Calculated from the GC-FID peak integration areas (average of two assays).

The reactions are selective for benzofuranone 19 and the decomposition of $3 \mathrm{MBF}-\mathrm{O}$ to afford 20 (Scheme 1) seems to be a minor pathway. In the presence of CAT I, the selectivity for $\mathbf{1 9}$ is higher when using $0.3 \mathrm{~mol} \%$ catalyst. Furthermore, the most selective catalyst is the cationic porphyrin III that affords 19 with a selectivity greater than $98 \%$, while CATs I and II afford 19 with maximum selectivities of $92 \%$ and $87 \%$, respectively. The higher selectivity observed with CAT III can be explained by the more acidic conditions used for this catalyst being more favorable for the epoxide rearrangement.

\section{Materials and Methods}

\subsection{Reagents and Instrumentation}

All the reagents and solvents were used as received without further purification. The reagents benzofuran (BF), 2-methylbenzofuran (2MBF), 3-methylbenzofuran (3MBF), chlorobenzene, salicylaldehyde redist. $\geq 99 \%$ and $\mathrm{H}_{2} \mathrm{O}_{2} 30 \% \mathrm{w} / \mathrm{w}$ (Pedrogen) were purchased from Sigma-Aldrich (St. Louis, MO, USA). Ammonium acetate and glacial acetic acid were p.a. grade and acquired from Merck (Darmstadt, Germany). Acetonitrile, toluene, ethyl acetate, dichloromethane, and methanol were all p.a. grades and acquired from Fisher Chemicals (Waltham, MA, USA). The manganese porphyrins were prepared using literature procedures $[32,33,35]$. The chromatographic purifications were carried out using silica gel $60 \mathrm{~F}_{254}$ from Merck.

${ }^{1} \mathrm{H}$ NMR spectra (1D and 2D) were recorded on Bruker Avance instruments (Wissembourg, France) operating at a frequency of 300 or $400 \mathrm{MHz}$ for ${ }^{1} \mathrm{H}$ experiments and 75 or $100 \mathrm{MHz}$ for ${ }^{13} \mathrm{C}$ experiments, with sample temperatures of $22{ }^{\circ} \mathrm{C}$ and using $\mathrm{CDCl}_{3}$ or DMSO- $\mathrm{d}_{6}$ as solvent (Euroisotop). Unless otherwise specified, TMS was used as an internal reference.

The GC-FID analyses were performed using a Varian 3900 chromatograph (Palo Alto, CA, USA) and GC-MS analyses were performed on a Finnigan Trace GC-MS (Thermo Quest CE instruments, 
Waltham, MA. USA) using helium as the carrier gas. In both cases, DB-5-type-fused silica Supelco capillary columns were used ( $30 \mathrm{~m}, 0.25 \mathrm{~mm}$ i.d.; $0.25 \mu \mathrm{m}$ film thickness) and the temperature program was: $70{ }^{\circ} \mathrm{C}(1 \mathrm{~min}), 20^{\circ} \mathrm{C} \mathrm{min}-1$, and $200^{\circ} \mathrm{C}(5 \mathrm{~min})$. The injector temperature was set at $200^{\circ} \mathrm{C}$ and the detector temperature was set at $250^{\circ} \mathrm{C}$.

High-resolution electrospray ionization mass spectra (HR-ESI-MS) were obtained using an LTQ-Orbitrap XL mass spectrometer (Thermo Scientific, Waltham, MA. USA). Evaporated samples were dissolved in acetonitrile while reaction mixtures were directly injected and infused into the electrospray ion source at $10 \mu \mathrm{L} \cdot \mathrm{min}^{-1}$. The spectrometer was operated in the positive ionization mode with the capillary voltage set to $+3.1 \mathrm{kV}$, sheath gas flow to 6 , and the temperature of the ion transfer capillary to $275^{\circ} \mathrm{C}$.

\subsection{Catalytic Experiments}

The catalytic experiments were performed using the following procedure: The substrate $(0.3 \mathrm{mmol})$, the catalyst $0.3 \mathrm{~mol} \%(1 \mu \mathrm{mol})$ or $0.7 \mathrm{~mol} \%(2 \mu \mathrm{mol})$, and the co-catalyst $(0.12 \mathrm{mmol}$, ammonium acetate for catalysts I and II or acetic acid for catalyst III) were dissolved in $2 \mathrm{~mL}$ of acetonitrile and stirred at 16 to $20^{\circ} \mathrm{C}$ protected from light. When the reactions were followed by GC analysis, chlorobenzene $(0.3 \mathrm{mmol})$ was added to the reaction mixture as an internal standard. Aqueous hydrogen peroxide $(30 \% \mathrm{w} / \mathrm{w})$ diluted in acetonitrile $(1: 10)$ was added to the reaction mixture at a constant rate of $0.6 \mathrm{~mL} / \mathrm{h}$ ( 2 mol equivalents relative to the substrate/h) through a syringe pump (KDScientific, KDS 200, Havard Bioscience, Holliston, MA, EUA).

For the comparison of catalyst performance, the reactions were followed by GG-FID analysis every 30 min until a full conversion was reached or when no evolution was detected in two successive analyses. Quantification of SA in the reaction media was performed by the GC internal standard method after calculation of the $\mathbf{S A}$ response factor.

The final reaction mixtures were fractionated by TLC using a mixture of toluene:ethyl acetate (3:1) as solvent. The compounds were revealed on TLC plates with concentrated $\mathrm{H}_{2} \mathrm{SO}_{4}$ applied in a small strip on one of the side edges of the TLC plates. The compounds were removed from silica with $\mathrm{CH}_{2} \mathrm{Cl}_{2}$. For ${ }^{1} \mathrm{H} \mathrm{NMR}$ analysis of the total reaction mixtures, the final reaction was passed through a small plug of alumina, eluted with dichloromethane, and the solvent evaporated at $30^{\circ} \mathrm{C}$.

\subsection{Characterization Data of Isolated Fractions}

Salicylaldehyde (1) ${ }^{1} \mathrm{H}$ NMR $\left(\mathrm{CDCl}_{3}, 300 \mathrm{MHz}\right) \delta(\mathrm{ppm}): 6.99-7.06(\mathrm{~m}, 2 \mathrm{H}, \mathrm{Ar}-\mathrm{H}), 7.52-7.59(\mathrm{~m}, 2 \mathrm{H}$, Ar-H), 9.91 (s, 1H, -CHO), $11.03(\mathrm{~s}, 1 \mathrm{H},-\mathrm{OH}) .{ }^{1} \mathrm{H}$ NMR $\left(\right.$ DMSO-d $\left._{6}, 400 \mathrm{MHz}\right) \delta(\mathrm{ppm}): 6.96(\mathrm{t}, 1 \mathrm{H}$, $\mathrm{J}=7.8 \mathrm{~Hz}, \mathrm{Ar}-\mathrm{H}), 7.00(\mathrm{~d}, 1 \mathrm{H}, \mathrm{J}=7.8 \mathrm{~Hz}, \mathrm{Ar}-\mathrm{H}), 7.52(\mathrm{t}, 1 \mathrm{H}, \mathrm{J}=7.8 \mathrm{~Hz}, \mathrm{Ar}-\mathrm{H}), 7.66(\mathrm{~d}, 1 \mathrm{H}, \mathrm{J}=7.8 \mathrm{~Hz}$, $\mathrm{Ar}-\mathrm{H}), 10.26$ (s, $1 \mathrm{H},-\mathrm{CHO}) .{ }^{13} \mathrm{C}$ NMR $\left(\mathrm{CDCl}_{3}, 75 \mathrm{MHz}\right) \delta$ (ppm): 117.6 (C-3), $119.8(\mathrm{C}-1), 120.6(\mathrm{C}-5)$, 133.7 (C-6), $137.0(\mathrm{C}-4), 161.6(\mathrm{C}-2), 196.6(\mathrm{CHO})$. MS (EI) m/z: $122.1\left[\mathrm{IM}^{+} \bullet\right.$. HRMS (ESI ${ }^{+}$) m/z: 122.06030 $[\mathrm{M}+\mathrm{H}]^{+}$, imine form, calculated: $122.06004, \Delta \mathrm{m}: 2.1 \mathrm{ppm}$.

Compound (5) Carbon numbering in accordance with Scheme 2b. ${ }^{1} \mathrm{H}$ NMR (DMSO- $\left.\mathrm{d}_{6}, 400 \mathrm{MHz}\right) \delta$ (ppm): $6.51(\mathrm{~d}, 1 \mathrm{H}, \mathrm{J}=1.5 \mathrm{~Hz}, \mathrm{H}-3), 6.84-6.92(\mathrm{~m}, 3 \mathrm{H}, \mathrm{H}-2,6,7), 7.01(\mathrm{dd}, 1 \mathrm{H}, \mathrm{J}=7.6$ and $1.0 \mathrm{~Hz}, \mathrm{H}-4)$, $7,14(\mathrm{t}, 1 \mathrm{H}, \mathrm{J}=7.6$ and $1.0 \mathrm{~Hz}, \mathrm{H}-5), 7.26\left(\mathrm{dt}, 1 \mathrm{H}, \mathrm{J}=7.6\right.$ and $\left.1.7 \mathrm{~Hz}, \mathrm{H}-4^{\prime}\right), 7.48(\mathrm{dd}, 1 \mathrm{H}, \mathrm{J}=7.6$ and $\left.1.7 \mathrm{~Hz}, \mathrm{H}-6^{\prime}\right), 7.52\left(\mathrm{dt}, 1 \mathrm{H}, \mathrm{J}=7.6\right.$ and $\left.1.7 \mathrm{~Hz}, \mathrm{H}-5^{\prime}\right), 7.82\left(\mathrm{dd}, 1 \mathrm{H} . \mathrm{J}=7.6\right.$ and $\left.1.7 \mathrm{~Hz}, \mathrm{H}-3^{\prime}\right), 8.70$ (s-broad, 1H, OH), $9.96(\mathrm{~s}, 1 \mathrm{H}, \mathrm{CHO})$. HRMS (ESI $\left.{ }^{+}\right) \mathrm{m} / \mathrm{z}: 256.09682[\mathrm{M}+\mathrm{H}]^{+}$, imine form, calculated: 256.09744, $\Delta \mathrm{m}: 2.4 \mathrm{ppm}$.

1-(2-Hydroxyphenyl)-2-oxopropyl acetate (16, oxo-form) ${ }^{1} \mathrm{H}$ NMR $\left(\mathrm{CDCl}_{3}, 400 \mathrm{MHz}\right) \delta$ (ppm): 2.20 (s, 3H, $\left.-\mathrm{CH}_{3}\right), 2.21\left(\mathrm{~s}, 3 \mathrm{H},-\mathrm{CH}_{3}\right), 6.12\left(\mathrm{~s}, 1 \mathrm{H}, \mathrm{H}-1^{\prime}\right), 6.90-6.98$ (m, 2H, H-Ar), 7.24-7.32 (m, 2H, H-Ar). APT

${ }^{13} \mathrm{C} \mathrm{NMR}\left(\mathrm{CDCl}_{3}, 75 \mathrm{MHz}\right) \delta(\mathrm{ppm}): 20.8\left(\mathrm{CH}_{3}\right.$ from $\left.\mathrm{OAc}\right), 26.6\left(\mathrm{CH}_{3}-\mathrm{C}=\mathrm{O}\right), 78.4\left(\mathrm{Cl}^{\prime}\right), 118.1(\mathrm{C} 3)$, 118.5 (C6), 121.3 (C5), 129.8 (C4), 131.5 (C6a), 155.4 (C2), 170.6 (COO), 203.9 (C=O). HRMS (ESI ${ }^{+}$) m/z: 231.06178 [M + Na] $]^{+}$, calculated: 231.06278, $\Delta \mathrm{m}: 4.3$ ppm. $\mathrm{MS}^{2} 231.06:\left(-\mathrm{CH}_{3} \mathrm{COOH}\right) \mathrm{m} / \mathrm{z} 171.04095$. 
3-methylbenzofuran-2(3H)-one (19) ${ }^{1} \mathrm{H} \mathrm{NMR}\left(\mathrm{CDCl}_{3}, 300 \mathrm{MHz}\right) \delta(\mathrm{ppm}): 1.58($ broad d, 3H, J = $7.4 \mathrm{~Hz}$, $\left.-\mathrm{CH}_{3}\right), 3.72(\mathrm{q}, 1 \mathrm{H}, \mathrm{J}=7.4 \mathrm{~Hz},-\mathrm{CH}), 7.11(\mathrm{~d}, 1 \mathrm{H}, \mathrm{J}=7.6 \mathrm{~Hz}, \mathrm{H}-\mathrm{Ar}), 7.16(\mathrm{dd}, \mathrm{J}=7.6$ and $0.95 \mathrm{~Hz}, 1 \mathrm{H}$, H-Ar) 7.25-7.33 (m, 2H, H-Ar). MS (EI) m/z: $147.8[\mathrm{M}]^{+\bullet}$, calculated 148.0.

$2^{\prime}$-hydroxyacetophenone (20) ${ }^{1} \mathrm{H}$ NMR $\left(\mathrm{CDCl}_{3}, 300 \mathrm{MHz}\right) \delta(\mathrm{ppm}): 2.64\left(\mathrm{~s}, 3 \mathrm{H},-\mathrm{CH}_{3}\right), 6.90(\mathrm{ddd}, 1 \mathrm{H}$, $\mathrm{J}=1.0, \mathrm{~J}=6.6$ and $\mathrm{J}=8.5 \mathrm{~Hz}, \mathrm{H}-4^{\prime}$ or $\left.\mathrm{H}-5^{\prime}\right), 6.98\left(\mathrm{dd}, 1 \mathrm{H}, \mathrm{J}=1.0\right.$ and $\mathrm{J}=8.5 \mathrm{~Hz}, \mathrm{H}-3^{\prime}$ or $\left.\mathrm{H}-6^{\prime}\right), 7.48$ $\left(\mathrm{ddd}, 1 \mathrm{H}, \mathrm{J}=1.7, \mathrm{~J}=6.6\right.$ and $\mathrm{J}=8.5 \mathrm{~Hz}, \mathrm{H}-4^{\prime}$ or $\left.\mathrm{H}-5^{\prime}\right), 7.74\left(\mathrm{dd}, 1 \mathrm{H}, \mathrm{J}=1.7\right.$ and $\mathrm{J}=8.5 \mathrm{~Hz}, \mathrm{H}-3^{\prime}$ or $\left.\mathrm{H}-6^{\prime}\right)$. MS (EI) m/z: $135.8[\mathrm{M}]^{+\bullet}$, calculated 136.0.

\section{Conclusions}

Three second generation $\mathrm{Mn}$ (III) porphyrins carrying neutral or cationic substituents (I, II, and III) were shown to be efficient catalysts for the oxidation of 2,3-benzofurans with hydrogen peroxide at room temperature and in the presence of an appropriate co-catalyst (ammonium acetate or acetic acid). Using an Ox/S ratio of 4 and porphyrin I with ammonium acetate co-catalyst as a reference system, significant differences were seen in the transformations observed for benzofuran (BF), 2-methylbenzofuran (2MBF), and 3-methylbenzofuran (3MBF). For example, with 3MBF, only two products were obtained: 3-methylbenzofuran-2(3H)-one) (major product) and 2'-hydroxyacetophenone (minor product). This behavior can be contrasted with the plethora of products obtained for $\mathbf{B F}$, where depending upon the work-up conditions of the reaction, 15 products were characterized by tandem mass spectrometry. For 3MBF, extremely high conversion (99\%) and selectivity $(99 \%)$ were achieved using the cationic catalyst III and acetic acid as co-catalyst.

The transformations observed can be justified by the initial epoxidation of the furan rings followed by subsequent reactions. The benzofuran and 2-methylbenzofuran oxides undergo decarboxylation to salicylaldehyde, which was isolated as a reaction product and also reacted with the oxirane rings through nucleophilic attack. When using the neutral catalyst CAT I and ammonium acetate co-catalyst, other products resulted from epoxide reactions with $\mathrm{NH}_{3}$ or acetic acid. Additional products are justified by the formation of imines and intramolecular cyclisation through imine-double bond reactions.

From a comparison of the present results on the oxidation of benzofurans in the presence of $\mathrm{Mn}(\mathrm{III})$ porphyrins with those previously reported for biomimetic oxidation by an $\mathrm{Fe}(\mathrm{III})$ porphyrin in ethanol [28], it can be observed that the hydroxylation of the benzene ring is minimized (it is not observed in the isolated products) and a number of new coupling reactions and transformation pathways are detected.

Supplementary Materials: The following are available online at http://www.mdpi.com/2073-4344/10/1/62/s1. Section S1: Comparison of catalytic activity of Mn(III) porphyrins in the oxidation of benzofurans at $0.7 \mathrm{~mol} \%$ loading. Section S2: Mass spectrometry studies of BF and 2MBF oxidation reactions in the presence of CAT I. Section S3. NMR spectra of products and reaction mixtures.

Author Contributions: Conceptualization: S.L.H.R., M.G.P.M.S.N. and M.M.Q.S.; Methodology: S.M.G.P. and S.L.H.R.; Validation: M.G.P.M.S.N., C.J.M. and B.d.C.; Data Curation: S.M.G.P. and S.L.H.R.; Writing-Original Draft Preparation: S.L.H.R.; Writing-Review and Editing: C.J.M. and M.G.P.M.S.N.; Project Administration and Funding Acquisition, B.C. and C.J.M. All authors have read and agreed to the published version of the manuscript.

Funding: The work was supported by FCT/MCTES (Fundação para a Ciência e a Tecnologia/Ministério da Ciência, Tecnologia e Ensino Superior) under the financing program of the Portuguese Research Units REQUIMTE/LAQV (UID/QUI/50006/2019) and QOPNA (UID/QUI/00062/2019) through national funds and, where applicable, co-financed by the FEDER, within the PT2020 Partnership Agreement. The work was also financed by the University of Aveiro and the Portuguese NMR Network. S.M.G.P. also thanks the AgroForWealth project for a Pos-Doc grant (BPD/UI89/4413/2017).

Conflicts of Interest: The authors declare no conflicts of interest.

\section{References}

1. Chen, J.; Jiang, S.; Wang, J.; Renukuntla, J.; Sirimulla, S.; Chen, J. A comprehensive review of cytochrome P450 2E1 for xenobiotic metabolism. Drug Metab. Rev. 2019, 51, 178-195. [CrossRef] [PubMed] 
2. Olsen, L.; Oostenbrink, C.; Jørgensen, F.S. Prediction of cytochrome P450 mediated metabolism. Adv. Drug Metab. Rev. 2015, 86, 61-71. [CrossRef] [PubMed]

3. Foroozesh, M.; Sridhar, J.; Goyal, N.; Liu, J. Coumarins and P450s, Studies Reported to-Date. Molecules 2019, 24, 1620. [CrossRef] [PubMed]

4. Guengerich, F.P. Cytochrome P450 and chemical toxicology. Chem. Res. Toxicol. 2008, 21, 70-83. [CrossRef] [PubMed]

5. Simões, M.M.Q.; Pires, S.M.G.; Neves, M.G.P.M.S.; Cavaleiro, J.A.S. Oxidative transformations of organic compounds mediated by metalloporphyrins as catalysts. In Handbook of Porphyrin Science; Kadish, K.M., Smith, K.M., Guillard, R., Eds.; World Scientific: Singapore, 2016; Volume 44, p. 197.

6. Zhao, M.; Ou, S.; Wu, C.-D. Porous metal-organic frameworks for heterogeneous biomimetic catalysis. Acc. Chem. Res. 2014, 47, 1199-1207. [CrossRef]

7. Bernadou, J.; Meunier, B. Biomimetic chemical catalysts in the oxidative activation of drugs. Adv. Synth. Catal. 2004, 346, 171-184. [CrossRef]

8. Lage, A.L.A.; Meireles, A.M.; Marciano, A.C.; Ribeiro, J.M.; Souza-Fagundes, E.M.; Martins, D.C.S. Ciprofloxacin degradation by first-, second-, and third-generation manganese porphyrins. J. Hazard. Mater. 2018, 360, 445-451. [CrossRef]

9. Rebelo, S.L.H.; Pereira, M.M.; Monsanto, P.V.; Burrows, H.D. Catalytic oxidative degradation of s-triazine and phenoxyalkanoic acid based herbicides with metalloporphyrins and hydrogen peroxide: Identification of two distinct reaction schemes. J. Mol. Catal. A Chem. 2009, 297, 35-43. [CrossRef]

10. Rebelo, S.L.; Linhares, M.; Simões, M.M.; Silva, A.M.; Neves, M.G.P.; Cavaleiro, J.A.; Freire, C. Indigo dye production by enzymatic mimicking based on an iron (III) porphyrin. J. Catal. 2014, 315, 33-40. [CrossRef]

11. Linhares, M.; Rebelo, S.L.H.; Simões, M.M.; Silva, A.M.; Neves, M.G.P.; Cavaleiro, J.A.; Freire, C. Biomimetic oxidation of indole by Mn (III) porphyrins. Appl. Catal. A Gen. 2014, 470, 427-433. [CrossRef]

12. Pires, S.M.; Simões, M.M.; Santos, I.C.; Rebelo, S.L.; Paz, F.A.A.; Neves, M.G.P.; Cavaleiro, J.A. Oxidation of organosulfur compounds using an iron (III) porphyrin complex: An environmentally safe and efficient approach. Appl. Catal. B: Environ. 2014, 160-161, 80-88. [CrossRef]

13. Santos, E.H.; Carvalho, C.; Terzi, C.M.; Nakagaki, S. Recent advances in catalyzed sequential reactions and the potential use of tetrapyrrolic macrocycles as catalysts. Molecules 2018, 23, 2796. [CrossRef] [PubMed]

14. da Silva, G.; Pires, S.M.; Silva, V.L.; Simões, M.M.; Neves, M.G.P.; Rebelo, S.L.; Silva, A.M.S.; Cavaleiro, J.A.S. A green and sustainable method for the oxidation of 1,3-dihydrobenzo[c]thiophenes to sulfones using metalloporphyrin complexes. Catal. Commun. 2014, 56, 68-71. [CrossRef]

15. Berijani, K.; Farokhi, A.; Hosseini-Monfared, H.; Janiak, C. Enhanced enantioselective oxidation of olefins catalyzed by Mnporphyrin immobilized on graphene oxide. Tetrahedron 2018, 74, 2202-2210. [CrossRef]

16. Neves, C.M.B.; Tomé, J.P.C.; Hou, Z.; Dehaen, W.; Hoogenboom, R.; Neves, M.G.P.; Simões, M.M.Q. Oxidation of monoterpenes catalysed by a water-soluble MnIIIPEG-porphyrin in a biphasic medium. ChemCatChem 2018, 10, 2804-2809. [CrossRef]

17. Maljutenko, K.; Borovkov, V.; Kananovich, D.; Järving, I.; Lopp, M. Aerobic cascade oxidation of substituted cyclopentane-1, 2-diones using metalloporphyrin catalysts. Tetrahedron 2018, 74, 661-664. [CrossRef]

18. Connelly, J.C.; Connor, S.C.; Monte, S.; Bailey, N.J.C.; Borgeaud, N.; Holmes, E.; Troke, J.; Nicholson, J.K.; Gavaghan, C.L. Application of directly coupled high performance liquid chromatography-NMR-mass spectometry and 1H NMR spectroscopic studies to the investigation of 2,3-benzofuran metabolism in sprague-dawley rats. Drug Metab. Dispos. 2002, 30, 1357-1363. [CrossRef]

19. Linhares, M.; Rebelo, S.L.H.; Biernacki, K.; Magalhães, A.L.; Freire, C. Biomimetic One-Pot Route to Acridine Epoxides. J. Org. Chem. 2015, 80, 281-289. [CrossRef]

20. Nevagi, R.J.; Dighe, S.N.; Dighe, S.N. Biological and medicinal significance of benzofuran. Eur. J. Med. Chem. 2015, 97, 561-581. [CrossRef]

21. Khanam, H. Shamsuzzaman, Bioactive benzofuran derivatives: A review. Eur. J. Med. Chem. 2015, 97, 483-505. [CrossRef]

22. Hiremathad, A.; Patil, M.R.; Chethana, K.R.; Chand, K.; Santos, M.A.; Keri, R.S. Benzofuran: An emerging scaffold for antimicrobial agents. RSC Adv. 2015, 5, 96809-96828. [CrossRef]

23. Dawood, K.M. Benzofuran derivatives: A patent review. Expert Opin. Ther. Pat. 2013, 23, $1133-1156$. [CrossRef] [PubMed] 
24. Xie, F.; Zhu, H.; Zhang, H.; Lang, Q.; Tang, L.; Huang, Q.; Yu, L. In vitro and in vivo characterization of a benzofuran derivative, a potential anticancer agent, as a novel Aurora B kinase inhibitor. Eur. J. Med. Chem. 2015, 89, 310-319. [CrossRef] [PubMed]

25. Tang, H.-J.; Zhang, X.-W.; Yang, L.; Li, W.; Li, J.-H.; Wang, J.-X.; Chen, J. Synthesis and evaluation of xanthine oxidase inhibitory and antioxidant activities of 2-arylbenzo[b]furan derivatives based on salvianolic acid C. Eur. J. Med. Chem. 2016, 124, 637-648. [CrossRef] [PubMed]

26. Zha, X.; Lamba, D.; Zhang, L.; Lou, Y.; Xu, C.; Kang, D.; Chen, L.; Xu, Y.; Zhang, L.; De Simone, A.; et al. Novel Tacrine-benzofuran hybrids as potent multitarget-directed ligands for the treatment of Alzheimer's disease: Design, synthesis, biological evaluation, and X-ray crystallography. J. Med. Chem. 2016, 59, $114-131$. [CrossRef]

27. Sauter, M.; Adam, W. Oxyfunctionalization of benzofurans by singlet oxygen, dioxiranes, and peracids: Chemical model studies for the DNA-damaging activity of benzofuran dioxetanes (oxidation) and epoxides (alkylation). Acc. Chem. Res. 1995, 28, 289-298. [CrossRef]

28. Rebelo, S.L.H.; Pires, S.M.G.; Simões, M.M.Q.; Medforth, C.J.; Cavaleiro, J.A.S.; Neves, M.G.P. A green and versatile route to highly functionalized benzofuran derivatives using biomimetic oxygenation. ChemistrySelect 2018, 3, 1392-1403. [CrossRef]

29. Rebelo, S.L.H.; Moniz, T.; Medforth, C.J.; Castro, B.; Rangel, M. EPR spin trapping studies of $\mathrm{H}_{2} \mathrm{O}_{2}$ activation in metaloporphyrin catalyzed oxygenation reactions: Insights on the biomimetic mechanism. Mol. Catal. 2019, 475, 110500. [CrossRef]

30. Costa, P.; Linhares, M.; Rebelo, S.L.H.; Neves, M.G.P.; Freire, C. Direct access to polycyclic peripheral diepoxy-mesoquinone derivatives from acene catalytic oxidation. RSC Adv. 2013, 3, 5350-5353. [CrossRef]

31. Rebelo, S.L.H.; Simões, M.M.Q.; Neves, M.G.P.; Cavaleiro, J.A.S. Oxidation of alkylaromatics with hydrogen peroxide catalysed by manganese(III) porphyrins in the presence of ammonium acetate. J. Mol. Catal. 2003, 201, 9-22. [CrossRef]

32. Rebelo, S.L.H.; Silva, A.M.N.; Medforth, C.J.; Freire, C. Iron (III) Fluorinated Porphyrins: Greener Chemistry from Synthesis to Oxidative Catalysis Reactions. Molecules 2016, 21, 481. [CrossRef] [PubMed]

33. Almeida, J.; Silva, A.M.N.; Rebelo, S.L.H.; Cunha-Silva, L.; Rangel, M.; Castro, B.; Leite, A.; Silva, A.M.G. Synthesis and coordination studies of 5-(4'-carboxyphenyl)-10,15,20-tris(pentafluorophenyl)porphyrin and its pyrrolidine-fused chlorin derivative. New J. Chem. 2018, 42, 8169-8179. [CrossRef]

34. Rocha, M.; Rebelo, S.L.H.; Freire, C. Enantioselective arene epoxidation under mild conditions by Jacobsen catalyst. Appl. Catal. A Gen. 2013, 460-461, 116-123. [CrossRef]

35. De Paula, R.; Simões, M.M.Q.; Neves, M.G.P.; Cavaleiro, J.A.S. Homogeneous olefin epoxidation catalysed by an imidazolium-based manganese porphyrin. Catal. Commun. 2008, 10, 57-60. [CrossRef]

36. Takahashi, M.; Micalizio, G.C. Regio- and stereoselective cross-coupling of substituted olefins and imines. J. Am. Chem. Soc. 2007, 129, 7514-7516. [CrossRef]

(C) 2020 by the authors. Licensee MDPI, Basel, Switzerland. This article is an open access article distributed under the terms and conditions of the Creative Commons Attribution (CC BY) license (http://creativecommons.org/licenses/by/4.0/). 